\title{
Effect of Organic Selenium and Zinc on the Performance and Egg Quality of Japanese Quails
}

\section{-Author(s)}

Cruz VC

Fernandez IB ${ }^{2}$

$1 \mathrm{PhD}$, Assistant Professor, Faculdade de Zootecnia, Universidade Estadual Paulista (UNESP) - Dracena. E-mail: valquíria@ dracena.unesp.br

2 Student, FAPESP grantee, Faculdade de Zootecnia, Universidade Estadual Paulista (UNESP) - Dracena. E-mail: isa_bfernandez@ hotmail.com

\section{-Mail Adress}

Valquíria Cação da Cruz

UNESP

Faculdade de Zootecnia - Campus de Dracena Rod. Cmte. João Ribeiro de Barros, SP 294 $\mathrm{Km} 651$

17.900-000. Dracena, SP, Brasil.

Phone: 55-18-38218200

e-mail:valquiria@dracena.unesp.br

\section{-Keywords}

Coturnix, Japanese quails, performance, quail eggs.

\section{-Acknowledgements}

The authors thank FAPESP for funding this study and for the grants given to the student, and to FUNDUNESP for the publication funding.

\begin{abstract}
The present study aimed at evaluating the effect of the dietary inclusion of organic trace minerals selenium and zinc on the performance and internal and external egg quality of Japanese quails submitted to heat stress. Data on egg production, feed conversion ( $\mathrm{kg}$ feed intake/ kg eggs and dozen eggs), egg weight, egg specific gravity, eggshell thickness and weight, Haugh unit, yolk index, albumen index and mortality (\%) of 144 quails were evaluated for 112 days, divided in eight cycles of 14 days. Birds were distributed according to a randomized block experimental design into four treatments (control; 0.3ppm Se;

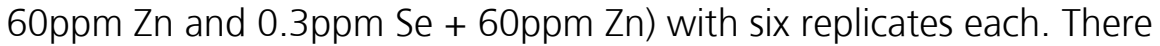
were no differences $(p>0.05)$ in egg production (\%), egg mass $(g / h e n /$ day), feed conversion per egg mass $(\mathrm{kg} / \mathrm{kg})$, feed conversion per dozen eggs $(\mathrm{kg} / \mathrm{dz})$, average egg weight $(\mathrm{g})$, egg specific gravity, eggshell thickness and weight (g), Haugh unit, yolk index, albumen index and mortality (\%). However, quails fed the combination of Se and Zn presented higher $(p<0.05)$ feed intake $(28.73 \mathrm{~g} / \mathrm{hen} /$ day). Those fed only organic selenium had higher average daily egg production (30.17 eggs/day), and those fed the diet only supplemented with zinc presented higher mortality $(p<0.05)$. The results of the present study suggest that the supplementation of organic trace minerals in Japanese quails diets submitted to heat stress does not significantly influence quail performance and internal egg quality, whereas the supplementation of the combination of organic $\mathrm{Zn}$ and Se increases feed intake.
\end{abstract}

\section{INTRODUCTION}

Presenting high profits and low initial investments, quail production has steadly grown. Egg production has yearly increased, and consequently, the search for new technologies. Feed corresponds to about $70 \%$ of quail production costs and it is responsible for final product quality (eggs). Among feed ingredients, trace minerals are highlighted, as they are essential for the maintenance of the physiological metabolism of animals. Trace minerals in general act as catalysts of a wide variety of enzyme systems (Vieira, 2005).

Some trace minerals protect and/or mitigate oxidative stress, such as when animals are exposed to high environmental temperatures. Studies showed that selenium (Se) and zinc ( $\mathrm{Zn}$ ) added as organic complexes to the feed of layers submitted to high environmental temperatures significantly increase feed intake, egg weight, and eggshell quality and weight.

The environmental impact caused by excessive mineral excretion in the soil has been frequently studied by researchers. This contamination is caused by the waste of production animals, which are commonly supplemented with mineral levels quite above their actual requirements. 
This is particularly the case in poultry and pig production. One of the solutions currently available is the supplementation of organic trace minerals. Many studies demonstrate that the higher bioavailability of organic trace minerals results in lower losses and better utilization by poultry, and consequently, better product quality. Organic trace minerals are absorbed faster as their transport through the intestine is easier, promoting better egg quality, higher weight gain, higher growth rate and, at the same time, reducing the effects of stress (Reddy et al., 1992).

Research on trace minerals for poultry and swine has not received attention in the last few years. Most studies were published 30 to 40 years ago, and often used purified diets and certainly animals which genetic potential is completely different from the modern strains.

Due to the limited number of studies on trace minerals for Japanese quails, the objective of the present study was to evaluate the performance and internal and external egg quality of Japanese quails (Coturnix coturnix japonica) fed diets supplemented with Se and Zn as an organic complex and submitted to heat stress.

\section{MATERIALS AND METHODS}

The experiment was carried out at the Poultry Sector of Universidade Estadual Paulista (UNESP), Dracena, Brazil. In this trial 144 female quails were housed at 60 days of age in a conventional quail house with 2 batteries of 24 cages made of galvanized wire. Cages were $0.17 \mathrm{~m}$ high $\times 0.35 \mathrm{~m}$ wide $\times 0.35 \mathrm{~m}$ deep. Feed was offered ad libitum in a trough feeder in the morning and in the evening. Water was also offered ad libitum in nipple drinkers. A lighting program of 19 hours of light was adopted. Internal house temperature was daily recorded using a maximum-minimum thermometer placed at the center of the house, and ranged between 42 and $44^{\circ} \mathrm{C}$ and 20 and $24^{\circ} \mathrm{C}$, respectively.

The experimental diets were based on corn and soybean meal, and formulated according to the recommendations of Murakami \& Ariki (1998), and diets were balanced according to the ingredient composition tables of Rostagno et al. (2005). The control diet or treatment 1 (Table 1) was supplemented with $0.3 p p m$ organic Se to compose treatment 2,60ppm organic $\mathrm{Zn}$ to compose treatment 3, and $0.3 p p m$ organic Se + $60 \mathrm{ppm}$ organic $\mathrm{Zn}$ to compose treatment 4.

A randomized block experimental design was applied, with four treatments (control; $0.3 p p m$ organic $\mathrm{Se}$; 60ppm organic $\mathrm{Zn}$ and $0.3 p p m$ organic Se +60 ppm organic Zn) of six replicates (cages/treatment), and the experimental unit was represented by one cage with six birds each.

Table 1 - Percentage and calculated composition of the diet supplied during lay.

\begin{tabular}{|c|c|}
\hline Ingredients \% & Control diet \\
\hline Corn & 63.507 \\
\hline Soybean meal & 27.622 \\
\hline Salt/ $\mathrm{NaCl}$ & 0.400 \\
\hline Mineral and vitamin supplement ${ }^{1}$ & 0.500 \\
\hline Calcitic limestone & 4.864 \\
\hline Dicalcium phosphate & 2.602 \\
\hline DL-methionine & 0.169 \\
\hline Lysine & 0.336 \\
\hline Selenium-methionine & 0 \\
\hline Zinc & 0 \\
\hline Total & 100.00 \\
\hline \multicolumn{2}{|l|}{ Calculated composition } \\
\hline Crude protein, (\%) & 18 \\
\hline Metabolizable energy, (kcal/kg) & 2800 \\
\hline Calcium, $(\%)$ & 2.50 \\
\hline Available phosphorus, (\%) & 0.55 \\
\hline Methionine+Cystine, (\%) & 0.76 \\
\hline Lysine, (\%) & 1.30 \\
\hline \multicolumn{2}{|c|}{$\begin{array}{l}1 \text { - Mineral and Vitamin supplement - Composition/kg product: Folic } \\
\text { acid, 61.75mg; Biotin, 25mg; Choline, 60,000mg; Niacin, 2,475mg; } \\
\text { Calcium pantothenate, 712.5mg; Vit. A, 1,562,500 IU; Vit. B1, 370mg; } \\
\text { Vit. B12, 5,000mcg; Vit. B2, 850mg; Vit. B6, 247.5mg; Vit. D3, 625,000 } \\
\text { IU; Vit. E, 3,125mg; Vit. K, 245mg; Copper, 1,875mg; lodine, 126.5mg; } \\
\text { Manganese, 11,437.5mg; Selenium, 57mg; Zinc, 15,057mg; Methionine, } \\
\text { 350g; Antioxidant, 100mg. Control diet supplemented with 0.3ppm Se } \\
\text { to compose treatment 2; Control diet supplemented with 60ppm Zn to } \\
\text { compose treatment 3; Control diet supplemented with 0.3ppm Se + } \\
\text { 60ppm Zn to compose treatment 4. }\end{array}$} \\
\hline
\end{tabular}

The following performance parameters were evaluated: average egg weight (g), egg production (\% eggs/treatment), egg mass (g/hen/day), feed intake (g/ hen/day), feed conversion per egg mass ( $\mathrm{kg}$ feed/kg eggs) and feed conversion per dozen eggs ( $\mathrm{kg}$ feed/dz eggs). Mortality was daily recorded. Feed intake and feed conversion ( $\mathrm{kg}$ feed/dozen eggs and $\mathrm{kg}$ feed $/ \mathrm{kg}$ eggs) data were analyzed at the end of each 14-day cycle and for total experimental period (eight cycles). In order to calculate daily egg production per treatment, eggs were daily collected and recorded per replicate at the end of each cycle (14 days) totaling eight cycles for the entire experimental period.

At the end of each 14-day cycle, total daily egg production of each experimental unit was submitted to analyses to determine specific gravity, albumen index, yolk index, albumen height, Haugh unit and eggshell thickness and weight.

Intact eggs were individually identified and weighed in a balance digital scale (BK 3000) with $0.001 \mathrm{~g}$ 
precision. Egg specific gravity was determined by the method of immersion in saline solution, according to the methodology described by Hamilton (1982). Seven solution with densities between 1.060 and 1.072 were prepared, with 0.002 increase per solution. Egg specific gravity was verified using a densimeter (Incoterm - OM-5565).

Albumen height was determined by breaking the previously identified and weighed eggs onto a completely black and smooth surface and measured between the external edge and yolk using a pachymeter (DIGIMES, 0-150 mm). Average albumen height values were applied to the formula of Card and Nesheim (1978) to calculate Haugh unit as: $\mathrm{HU}=100 \times \log (\mathrm{H}+7.57$ $\left.1.7 \mathrm{~W}^{0.37}\right)$, where: $\mathrm{H}=$ albumen height $(\mathrm{mm})$ and $\mathrm{W}=$ egg weight (g). Albumen index was calculated as the average between the highest and the lowest diameter.

Yolk index was determined by the method proposed by Solomon (1991). Yolk height (YH) and diameter (YD) were measured with the yolk still inside the albumen, and used to calculate yolk index as $\mathrm{YI}=\mathrm{YH} / \mathrm{YD}$.

Eggshells were washed under running water, and were exposed to environmental temperature for 48 hours for drying, after which they were weighed in a balance digital scale $(0.01 \mathrm{~g}$ precision). Average eggshell thickness was determined measuring three points of the eggshell equatorial region using a digital micrometer (DIGIMES, 0-25 mm precision).

Data were submitted to analysis of variance (ANOVA) using SAEG statistical package (2005). Mean were compared by the test of Tukey at $5 \%$ probability level.

\section{RESULTS AND DISCUSSION}

Table 2 shows average performance results of quails fed diets with different trace mineral inclusion levels during the 112-day lay period.

$\mathrm{FI}$ (feed intake), DEP (daily egg production) and Mort (mortality) were significantly $(p<0.05)$ influenced by the inclusion of the organic trace minerals selenium and zinc in the diet.

The results obtained for egg production, average egg weight, egg mass, feed conversion per kg eggs and per dozen eggs, and egg specific gravity were not different among treatments, which is consistent with the findings of Saldanha (2008).

Birds fed the diet containing Se+Zn (T4) presented the highest feed intake, which was not different ( $p>0.05$ ) from the birds fed the diets T1 and T2 (control and Se, respectively), but higher $(p<0.05)$ than the diet containing only $\mathrm{Zn}$ (T3). Different results were obtained by Lundenn (2001), Sechinato (2003), Albuquerque (2004) and Scatolini (2007), who found that the supplementation of diets with organic or inorganic trace mineral sources individually and/or combined did not have any effect $(p>0.05)$ on the feed intake of chickens.

Table 2 - Effect of organic Se and Zn addition on feed intake (FI), egg production (EP), average egg weight (AEW), egg mass (EM), feed conversion per egg mass (FCREM), feed conversion per egg mass (FCEM), feed conversion per dozen eggs (FCDZ) and daily egg production (DEP) and mortality (Mort) of Japanese quails between 60 and 172 days of age.

\begin{tabular}{|c|c|c|c|c|c|}
\hline \multirow{2}{*}{ Parameters } & \multicolumn{4}{|c|}{ Diet } & \multirow{2}{*}{ CV* } \\
\hline & T1 & T2 & T3 & T4 & \\
\hline $\mathrm{FI}$ (g/hen/day) & $26.48 \mathrm{AB}$ & $25.99 A B$ & $25.36 \mathrm{~B}$ & $28.73 \mathrm{~A}$ & 19.70 \\
\hline $\mathrm{EP}(\%)^{\mathrm{NS}}$ & 70.86 & 74.00 & 71.03 & 72.49 & 18.44 \\
\hline AEW $(g)^{N S}$ & 9.73 & 9.95 & 9.90 & 10.00 & 21.72 \\
\hline EM (g/hen/day) Ns & 8.77 & 9.29 & 8.75 & 9.15 & 21.72 \\
\hline FCREM $(\mathrm{kg} / \mathrm{kg})^{\mathrm{NS}}$ & 3.15 & 2.95 & 3.03 & 3.25 & 23.77 \\
\hline FCRDZ $(\mathrm{kg} / \mathrm{dz})^{\mathrm{NS}}$ & 0.376 & 0.372 & 0.371 & 0.383 & 21.47 \\
\hline $\mathrm{SG}\left(\mathrm{g} / \mathrm{cm}^{3}\right)^{\mathrm{NS}}$ & 1.066 & 1.068 & 1.066 & 1.066 & 4.43 \\
\hline DEP & $29.13 A B$ & $30.17 \mathrm{~A}$ & $29.63 A B$ & $28.70 \mathrm{~B}$ & 12.15 \\
\hline Mort (\%) & 4.14B & 4.14B & $4.98 \mathrm{~A}$ & 4.66AB & 13.44 \\
\hline
\end{tabular}

T1: control; T2: 0.3ppm Se; T3: 60ppm Zn; T4: 0.3ppm Se + 60ppm Zn. ${ }^{*} \mathrm{CV}$ : Coefficient of variation; $\mathrm{A}$ and $\mathrm{B}$ : means followed by different letters in the same row are different by the test of Tukey $(p<0.05)$; NS = non-significant by the test of Tukey ( $p>0.05)$.

On the other hand, in agreement with the present study, Lundenn (2001) and Sechinato (2003) also did not observe any improvement in feed conversion in Babcock layers supplemented with organic trace minerals as compared to inorganic. Lundenn (2001) also did not find any influence of organic or inorganic trace minerals ( $\mathrm{Zn}$ and $\mathrm{Mn}$ ) on the feed conversion ratio of 40- to 60-week-old Babcock layers. Scatolini (2007) also reported that the feed conversion of layers did not improve when these were fed organic trace minerals.

Correia et al. (2000) evaluated the supplementation of organic selenium in layer diets and also did not observe significant difference in egg specific gravity.

Treatments significantly influenced daily egg production, with the quails fed the treatment including only Se (T2) producing 30.17 eggs/day, which was significantly difference from the egg production of birds fed the diet containing $\mathrm{Se}+\mathrm{Zn}$ (T4), which produced 28.70 eggs/day. However, the egg production by $\mathrm{T} 2$ and T4 birds were not statistically different $(p>0.05)$ from birds in treatments T1 and T3 (control and Zn inclusion, respectively), as shown in Table 2. 
These results are consistent with the findings of Lundeen (2001), who reported an interaction between organic trace minerals and calcium levels in the diet. That author included $3.5 \%$ calcium in the diet supplemented with organic trace minerals and confirmed their positive effect on egg production when comparing this treatment with the diet with no organic trace mineral supplementation and 4\% calcium inclusion. Kienholz (1992) found higher egg production in layers fed a diet with organic Zn supplementation and submitted to stress due to low dietary calcium level (3\%), which was not observed in the present experiment.

Quails supplemented only with Zn (T3) presented the highest mortality rate, which, however, were not statistically different ( $p>0.05)$ from those fed the diet with $\mathrm{Se}+\mathrm{Zn}$ inclusion (T4). The lowest mortality rates were obtained in the quails fed the control diet and only with $\mathrm{Se}$ ( $\mathrm{T} 1$ and $\mathrm{T} 2$, respectively), but these were not different ( $p>0.05)$ from the birds fed Se+Zn (T4).

Treatments did not influence ( $p>0.05)$ eggshell thickness and weight, Haugh unit, yolk index, or albumen index (Table 3). This result demonstrate that, independently of the dietary supplementation with organic trace minerals, there were no changes in egg internal or external quality, possibly because the inclusion of organic trace minerals was calculated relative to the inclusion levels of inorganic trace minerals, that is, organic trace mineral supplementation was excessive or deficient in relation to the requirements. However, when figures are examined, they show that the diets containing only $\mathrm{Se}$ (T2) or in combination with Zn (T4) promoted good $\mathrm{HU}$ values, of 87.43 and 87.25 , respectively, suggesting a positive effect of organic Se on the absorption and protection of fat-soluble compounds.

Table 3 - Effect of organic Se and Zn addition on eggshell thickness (EST), eggshell weight (ESW), Haugh unit $(\mathrm{HU})$, yolk index $(\mathrm{YI})$ and albumen index (Al) on the eggs of Japanese quails between 60 and 172 days of age.

\begin{tabular}{|c|c|c|c|c|c|}
\hline \multirow{2}{*}{ Parameters } & \multicolumn{4}{|c|}{ Diets } & \multirow{2}{*}{$\mathrm{CV}^{*}$} \\
\hline & T1 & T2 & T3 & T4 & \\
\hline EST $(\mathrm{mm})^{\mathrm{NS}}$ & 0.243 & 0.254 & 0.245 & 0.248 & 20.51 \\
\hline ESW $(g)^{\text {NS }}$ & 0.83 & 0.83 & 0.81 & 0.84 & 16.90 \\
\hline UHNS & 86.29 & 87.43 & 86.99 & 87.25 & 6.09 \\
\hline YINS & 0.37 & 0.35 & 0.37 & 0.37 & 43.70 \\
\hline AINS & 0.38 & 0.37 & 0.37 & 0.38 & 10.95 \\
\hline
\end{tabular}

T1: control; T2: 0.3ppm Se; T3: 60ppm Zn; T4: 0.3ppm Se + 60ppm Zn. ${ }^{*} \mathrm{CV}$ : Coefficient of variation; NS = non-significant by the test of Tukey $(p>0.05)$.

Correia et al. (2000) evaluated organic selenium supplementation in layer diets and did not find any significant differences in Haugh units, yolk index, albumen index, egg specific gravity and eggshell thickness, which is consistent with the present study. Conversely, Paton \& Cantor (2000) observed higher eggshell strength in the eggs of 80-week-old Babcock layers supplemented with organic selenium, and Lundeen (2001) verified better eggshell quality in the eggs of layers fed chelated Mn and Zn from 20 to 60 weeks of age.

The present study also obtained different results from those observed by Paik (2001), who evaluated the inclusion of organic Zn, Cu and Mn sources in layer diets, and obtained higher egg specific gravity and eggshell percentage in the eggs of layers fed organic trace minerals and that the association of organic $\mathrm{Zn}$ and $M n$ improved eggshell strength, showing the influence of Zn on the synthesis of the enzyme carbonic anhydrase.

Sechinato (2003) and Scatolini, (2007) also observed that the dietary inclusion of individual or combined organic trace minerals did not have any influence on Haugh units or yolk index. The study of Scatolini (2007) with layers showed that birds fed diets containing $\mathrm{Zn}$ and Se bound to an organic molecule presented higher HU, which was numerically observed in the present study.

The supplementation of the combination of organic $\mathrm{Mn}, \mathrm{Zn}$ and Se to Isa Brown layer diets tended to promote higher eggshell weight (Rutz et al., 2008). According to these authors, the dietary supplementation of layer diets with organic trace minerals improves eggshell quality, provided organic $\mathrm{Mn}$ and $\mathrm{Zn}$ are added in combination.

The results of the present study are consistent with the findings of Saldanha (2008), who did not find any differences in average egg quality results of semi-heavy layers in their second production cycle and fed diets supplemented with different trace mineral sources and levels ( $\mathrm{Zn}, \mathrm{Fe}, \mathrm{Mn}, \mathrm{Cu}, \mathrm{I}$ and Se).

Although organic trace minerals are more bioavailable, promoting better performance, no improvements in internal or external quality of the eggs or in the performance of quails when their diets were supplemented with organic selenium and zinc.

These results suggest that the studied supplemental levels of trace minerals may be higher than those required by quails for optimal performance, because selenium and zinc requirements were calculated based on the supplementation of inorganic sources of these trace minerals. It must be noted that the heat stress to which the birds were submitted was also higher 
than that found in other studies. Therefore, further studies are required (in quail production) as to the use, requirements, absorption, and bioavailability of chelated trace minerals. It must be noted that the heat stress to which the birds were submitted was also higher than that found in other studies. Therefore, further studies are required as to the use, requirements, absorption, and bioavailability of chelated trace minerals.

\section{REFERENCES}

Albuquerque R. Produção e qualidade da casca de ovos de galinhas poedeiras recebendo microminerais orgânicos em sua dieta. [tese]. Pirassununga (SP): Universidade de São Paulo; 2004.

Card LE, Nesheim MC. Producion avicola. Zaragoza: Editoral Acribia; 1978.

Correia GMG, Takata FN, Medeiros JP, Barros ACS, Aguiar JFC, Evêncio Neto J. Efeito do tempo de armazenamento sobre a qualidade de ovos de aves tratadas com selênio orgânico. Revista Brasileira de Zootecnia 2000; 29 (5):1440-1445.

Kienholz EW. Zinc methionine for stressed laying hens. Poultry Science 1992; 71:829-832.

Ludeen T. Mineral proteinates may have positive effect on shell quality. Feedstuffs 2001; 73(14):10-15.

Murakami AE, Ariki J. Produção de codornas japonesas. Jaboticabal: Funep; 1998. p. 79.

Paik I. Application of chelated minerals in animal production. Journal of Animal Science 2001; 14:191-198.

Paton ND, Cantor AH. Effect of dietary selenium source and storage on internal quality and shell strength of eggs. Poultry Science 2000; 70:116.

Reddy AB, Dwived JN, Ashmead AD. Mineral chelation generates profit. Misset. World Poultry 1992; 8:13-15.

Rostagno HS, Albino LFT, Donzele JL, Gomes PC, Oliveira RF, Lopes DC, Ferreira AS, Barreto SLT. Tabelas brasileiras para aves e suínos, composição dos alimentos e exigências nutricionais. 2nd ed. Viçosa (MG): UFV-DZO; 2005.

Rutz F, Pan EA, Xavier GB. Efeito de minerais orgânicos sobre o metabolismo e desempenho de aves [cited 2008 feb 11]. Available from: http://www.aveworld.com.br/index.php?documento=141.

Saeg - Sistema de análises estatísticas e genéticas [versão 9.0]. Viçosa: Universidade Federal de Viçosa; 2005.

Saldanha ESPB. Efeitos de minerais orgânicos no desempenho, qualidade de ovos e qualidade óssea de poedeiras semi-pesadas no segundo ciclo de produção [tese]. Botucatu (SP): Universidade Estadual Paulista; 2008.

Scatolini AM. Mn, Zn e Se associados a moléculas orgânicas na alimentação de galinhas poedeiras no segundo ciclo de produção [dissertação]. Jaboticabal (SP): Universidade Estadual Paulista; 2007.

Sechinato AS, Nakada S, Albuquerque R. Efeito da suplementação dietética de microminerais orgânicos no desempenho produtivo de poedeiras comerciais. Anais da Conferência Apinco; 2004; Campinas, São Paulo. Brasil. p. 49.

Solomon SE. Egg and eggshell quality. London: Wolfe Publishing; 1991. p.365.

Vieira SL. Minerais quelatados na nutrição animal. Anais do Simpósio de Nutrição de Aves e Suínos; 2005; Cascavel, Paraná. Brasil. p. 153-172. 

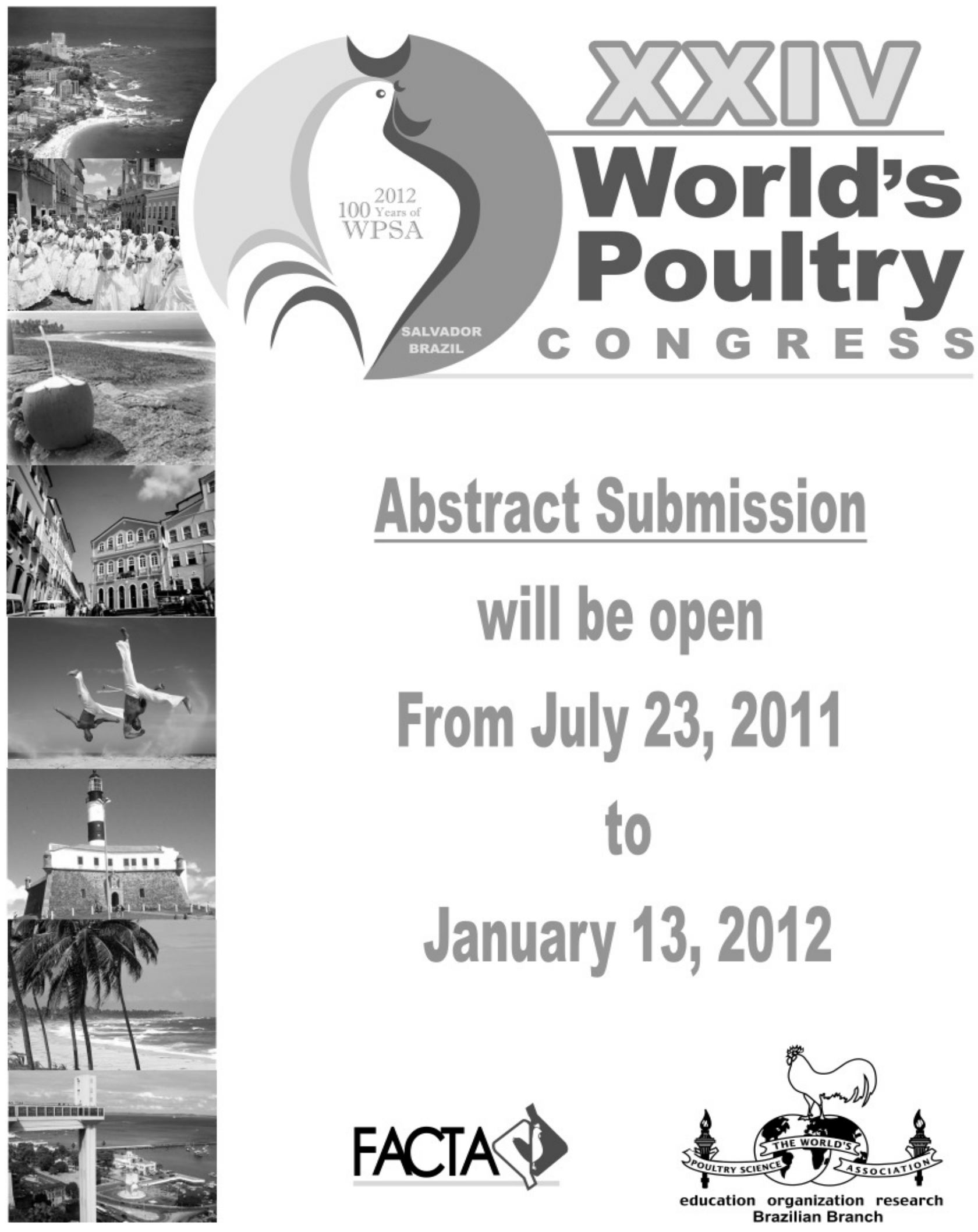

\section{Abstract Submission \\ will be open}

From July 23, 2011

to

January 13, 2012
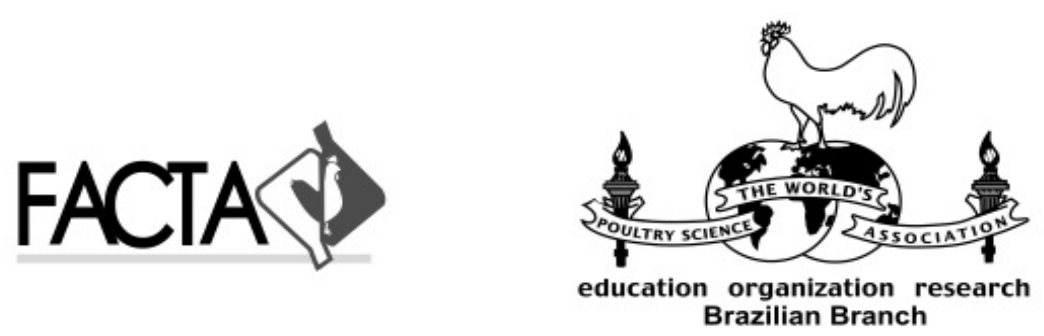

\section{WWW.WPC2012.COM}

